\title{
Quick and Inexpensive Method to Elaborate Tissue Punches Useful in Paraffin Tissue Microarrays
}

\author{
Método Rápido y Económico para la Elaboración de Dispositivos \\ de Punch Útiles en Microarreglos de Tejidos en Parafina
}

\author{
Rubén García-Garza; Edgar Paolo Rodríguez-Vidales \& Adolfo Soto-Domínguez
}

GARCÍA-GARCÍA, R.; RODRÍGUEZ-VIDALES, E. P. \& SOTO-DOMíNGUEZ, A. Quick and inexpensive method to elaborate tissue punches useful in paraffin tissue microarrays. Int. J. Morphol., 31(1):50-54, 2013.

SUMMARY: The tissue microarrays (TMAs) were first called multitumor block. In 1998 was described the current technique, that uses an innovated sampling method for more than 1,000 cylindrical paraffin tissue core biopsies in a single paraffin block. TMAs are now considered as a useful powerful research tool in Histology and Pathology laboratories, for the standardization of immunohistochemical techniques along with in situ hybridization. However, one disadvantage to its widespread use is the high cost of professional paraffin tissue punches, and the complexity in the development of homemade devices previously described in other studies. This study describes a step by step process to develop four different home-made devices made with materials that are common in hospitals and offices. These devices are useful in Histopathology laboratories to obtain paraffin blocks with until 360 samples of tissue, investing from two to fifteen dollars in the development of each device described.

KEY WORDS: Tissue microarrays; Inexpensive; Method.

\section{INTRODUCTION}

The tissue microarrays (TMAs) were first described by Battifora (1986), they called it as multitumor (sausage) tissue block. The current technique used to construct TMAs was implemented in 1998 (Kononen et al., 1998), using a novel sampling method to obtain more than 1,000 tissue cores within a single paraffin block. TMAs are now considered a powerful research tool, useful in the analysis of multiple samples either by routinely stains (Wang et al., 2002), immunohistochemistry (Martinez et al., 2011), in situ hybridization (Packestein et al., 2002; 2003; Van de Rijn \& Gilks, 2004) among other applications (Shergill et al., 2004; Obermann et al., 2005).

The construction of TMAs involves the use of a hollow device (punch), which is used to extract tissue fragments called "cores" from a single "donor" block, then these tissue cores are subsequently included in a "recipient" block, thereby obtaining a paraffin block that can contain hundreds of cores, from different donor blocks.

In some cases the preparation process of TMAs involves the use of various specialized equipment, for example, the Manual Tissue Arrayer MTA-1 ${ }^{\circledR}$ that allows the production of a recipient block with more than 500 cores within approximately 8 hours, but the main drawback is its high cost averaging between 9,000 and 10,000 euros.

Several authors have reported modifications to the technique of producing these TMAs, some using various home devices punch or different tools to construct the block receptor (Chen \& Zhou, 2005; Vogel \& Bueltmann, 2006). However, in most cases the development of these devices results to be difficult as they require certain manual dexterity, and in some cases it is necessary to use specialized tools which some of the laboratory professionals may not be familiar with, these requirements can make the production of TMAs more difficult.

The main objective of this report is to describe an inexpensive and simple preparation method to obtain paraffin tissue punches for TMAs. 


\section{MATERIAL AND METHOD}

This section will describe the methodology to prepare four different paraffin tissue punches to obtain $0.7,2,4$ and $6 \mathrm{~mm}$ cores, using inexpensive and everyday materials that can be found in hospitals and offices.

Paraffin tissue punch $\mathbf{0 . 7} \mathbf{~ m m}$. The preparation of this device requires two syringes from $5 \mathrm{ml}$ and $3 \mathrm{ml}$ without needle, one needle of $27 \mathrm{G} \times 13 \mathrm{~mm}$, one vacutainer of $22 \mathrm{G}$ x $1.5 \mathrm{~cm}$, U.T.W. $0.7 \times 40 \mathrm{~mm}$ (commonly used for the extraction of venous blood), tape measure, tape, one spring from a retractable pen, cutter pliers and a knife or cutter.

First carefully disassemble both syringes (Fig. 1A), remove the adaptor and cut the thread of the two syringes. Using the cutting pliers cut only the bevel of the $27 \mathrm{G} \mathrm{x}$ $13 \mathrm{~mm}$ needle (Fig. 1B), then using the knife reduce up to 4 $\mathrm{mm}$ the length of the largest needle of the vacutainer, this procedure should be done carefully avoiding distort or occlude the needle, finally cut the plastic to get a piece of 9 $\mathrm{mm}$ including the $4 \mathrm{~mm}$ needle (Fig. 1C).

After, having all the pieces, proceed to assemble the device as follows: introduce the $27 \mathrm{G} \mathrm{x} 13 \mathrm{~mm}$ needle in the $10 \mathrm{~mm}$ spring (if exceeds the size, it can be cut with the cutting pliers), with a plunger seal introduce them in the $3 \mathrm{ml}$ barrel syringe, the needle will protrude from the distal orifice. Introduce the small piece that was cut from the vacutainer in the needle, and now introduce all into the $5 \mathrm{ml}$ barrel syringe, the needle of the vacutainer protrudes through the distal orifice of the barrel. Finally both barrels are joined by the top with tape so they do not move from its place when pressure is applied to the donor or recipient block (Fig. 1D).
Paraffin tissue punches of 2,4 and $6 \mathrm{~mm}$. The preparation of these devices requires the use of two syringes from $5 \mathrm{ml}$ and $3 \mathrm{ml}$ without needle, skin biopsy needles (punch) of 2, 4 or $6 \mathrm{~mm}$; a wooden applicator from approximately $2 \mathrm{~mm}$ in diameter, tape, measuring metric tape, instant glue, spring from a retractable pen, cutter pliers and a knife or cutter.

First carefully disassemble both syringes, with the knife remove the adaptor and thread of the two syringes (Fig. $2 \mathrm{~A}$ ), then cut the punch approximately $2 \mathrm{~cm}$ from its tip (Fig. 2B). Obtain the $5 \mathrm{ml}$ syringe plunger seal and make a small hole in the center in order to introduce the part from the punch (Fig. 2C), put these pieces into the $5 \mathrm{ml}$ syringe barrel, observe that the needle of the punch is outside of the cylinder (the hole can be expanded if necessary). Introduce the $3 \mathrm{ml}$ syringe barrel and attach it to $5 \mathrm{ml}$ with tape, then insert the spring pen. After this, measure the distance from the tip of the punch to the upper portion of the spring, and the applicator is trimmed about $3 \mathrm{~mm}$ over the marked area. Furthermore, wound tape around the top of the applicator and put it into de spring, insert the plunger in the barrel (this will press the applicator through the spring). Finally with the spring pressured for the plunger seal, cut the applicator protruding more than $2 \mathrm{~mm}$ from the tip of the punch (Fig. 2D). It is important to consider that if the diameter of the wooden applicator is greater than the punch; it should be adjusted using the knife to reduce its diameter.

Preparation of the receiver block. For the preparation of the receiver block, is only necessary to use a paraffin block and the chosen device. First, is necessary to make a hole in the paraffin receiver block with the chosen punch, then get

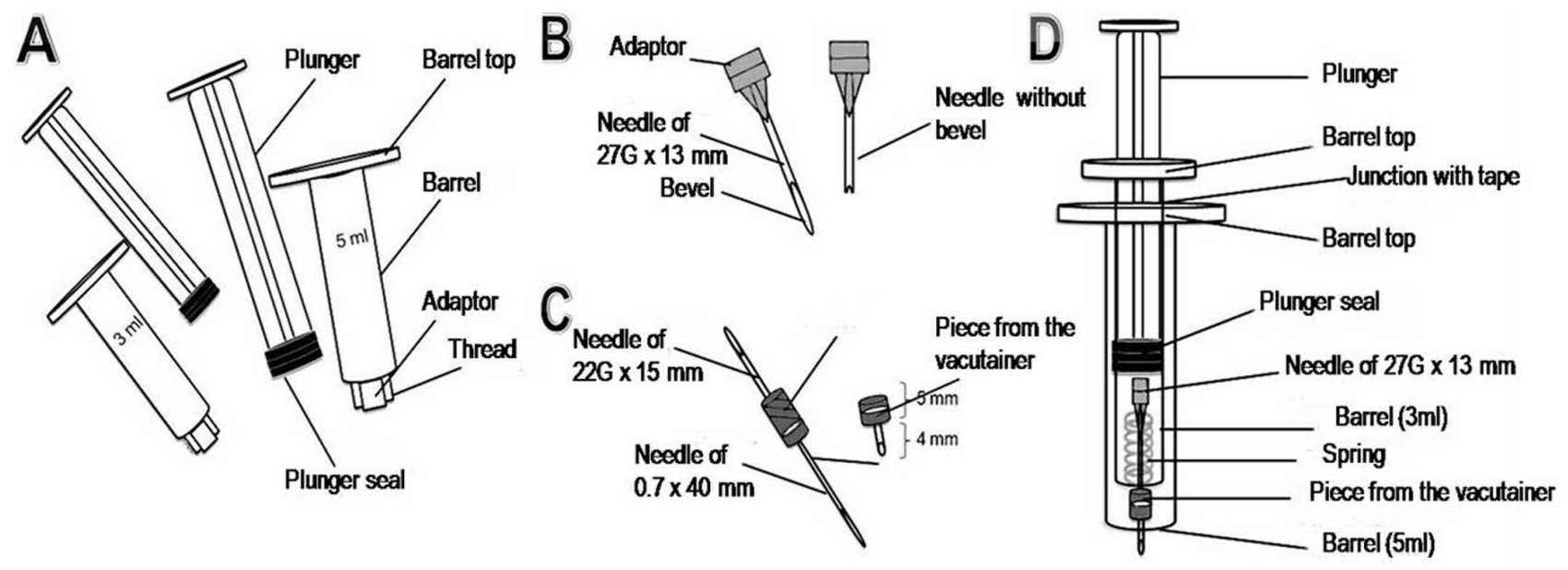

Fig. 1. Diagram to elaborate a $0.07 \mathrm{~mm}$ device. A. 5 and $3 \mathrm{ml}$ syringes and their components. B. $27 \mathrm{G} x 13 \mathrm{~mm}$ needle diagram. C. Vacutainer diagram and its components. D. Diagram shows the assembly of paraffin tissue punch of $0.7 \mathrm{~mm}$. 

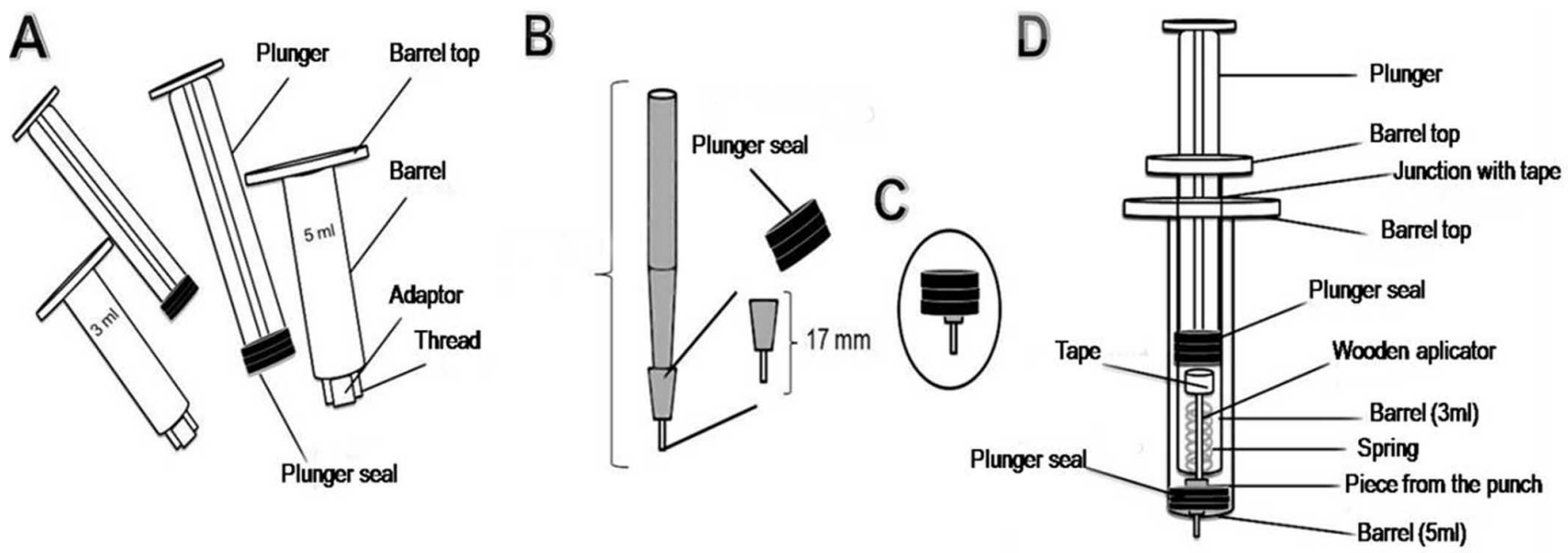

Fig. 2. Diagram to elaborate 2, 4 or $6 \mathrm{~mm}$ devices. A. 5 and $3 \mathrm{ml}$ syringes diagram and their components. B. Skin biopsy punch diagram. C. Piece from the skin biopsy punch with plastic plunger seal. D. Diagram shows the assembly of paraffin tissue punches of 2, 4 or $6 \mathrm{~mm}$.

the core from the donor block and transfer the core smoothly to the hole just made, it is important to let the core to protrude at least $1 \mathrm{~mm}$ to subsequently push it gently until the hole edge.

Incubation. Before cutting the block, it is essential to place the receiver block on a glass slide and incubate it in an oven at $56^{\circ} \mathrm{C}$ for $15-20$ minutes, subsequently without removing the glass slide cool them until they separated for themselves.

\section{RESULTS}

In this study we obtained punch devices of $0.7,2,4$ and $6 \mathrm{~mm}$ (Fig. 3A-D) in a quick and simple preparation way, it takes about 30 to 40 minutes in unskilled hands, these devices can be done with everyday materials in hospitals, clinics and offices. With the use of $0.7 \mathrm{~mm}$ punch, we were able to get paraffin blocks and slides with 360 samples with an approximate cost of \$ 2 dollars; also we could obtain blocks and slides of 42, 20 and 9 samples with the 2, 4 and $6 \mathrm{~mm}$ devices respectively (Fig. 3E-L), with an average cost of $\$ 15$ dollars each.

The use of a spring and the slide of plunger seal proved to be innovative and very useful, because without additional pressure movement of the stiletto it takes its proper place once again, this allows introducing the punch to the paraffin block again without interference, which reduces the time to produce TMAs.

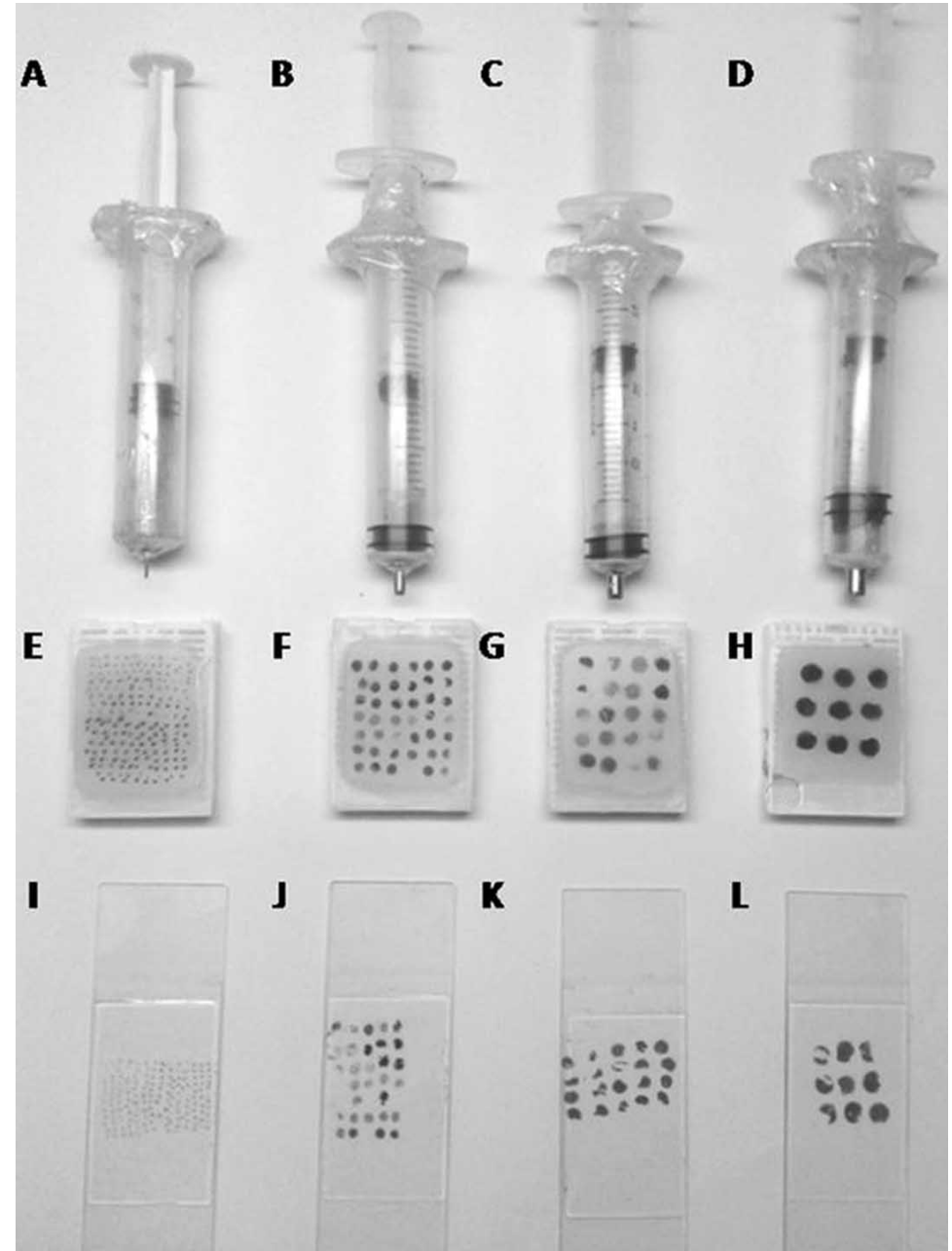

Fig. 3. Paraffin tissue punches of: A) $0.7 \mathrm{~mm}$, B) $2 \mathrm{~mm}$, C) $4 \mathrm{~mm}$, and D) 6 mm Recipient blocks with E) 360 cores, F) 42 cores, G) 20 cores, and H) 9 cores. Slides with: I) 400, J) 42 K) 20 and L) 9 samples of tissue stained with $\mathrm{H} \& \mathrm{E}$. 


\section{DISCUSSION}

There are several reports that describe the production of different homemade devices of $0.45,2,4$ and $6 \mathrm{~mm}$ (Chen \& Zhou.; Vogel \& Bueltman; Pires et al., 2006; Vogel, 2008; Hidalgo et al., 2003) However in some cases the elaboration requires the use of certain specialized tools, such as grinder and drill. In this study we intentionally avoid the use of electrical tools that could be in some cases difficult to obtain, most of materials used with the exception of cutting pliers are commonly used in various hospitals and offices, this allows a better reproduction of the method described in our study compared with those previously published.

Previous studies have reported an efficient production of low-cost devices with an average cost between $\$ 100$ and $\$ 300$ dollars (Pires et al.; Vogel; Hidalgo et al.). In this study, we obtained similar devices with an investment between \$2 to $\$ 15$ dollars to develop a $0.7 \mathrm{~mm}$ device; this punch does not require the use of a new skin biopsy punch which results to be the most expensive piece, but one alternative is that these punches can be reutilized (previous sterilization) from dermatology services.

Otherwise, it has been reported the obtaining of TMAs with more than over 558 cores using $0.6 \mathrm{~mm}$ diameters punches (Chen \& Zhou). In our report we could obtain TMAs with 360 samples, however, this may vary depending on the individual experience, the matrix size in the paraffin block, and one important point is the distance between each core.

It is important to mention that the development of the device and its use are quick and easy, the estimated time of preparation by an inexperienced person is between 30 to 40 minutes, and does not require any practice period, unlike those reported by other authors (Pires et al.).

None of the previous studies have reported the use of the vacutainer as useful punch tool, or the use of syringes and spring. In this report, the use of the plunger seal and spring is essential, because it prevents to insert and remove the stiletto every time is extracted or place a new core which increases the processing time of the block, also many times it requires additional skill that results tedious and less practical.

In conclusion, we developed four homemade devices useful to obtain TMAs. Some important advantages of these punches are: fast and easy process elaboration, low cost of materials which most of them are commonly found in hospitals and offices, and for the elaboration of these devices are not necessary electrical or difficult to obtain tools which may increase the cost.

GARCÍA-GARCÍA, R.; RODRÍGUEZ-VIDALES, E. P. \& SOTO-DOMÍNGUEZ, A. Método rápido y económico para la elaboración de dispositivos de punch útiles en microarreglos de tejidos en parafina. Int. J. Morphol., 31(1):45-49, 2013.

RESUMEN: Los microarreglos de tejido (TMAs) fueron llamados por primera vez como bloque multitumor. En 1998 se describió la técnica actual, que utiliza un novedoso método de muestreo para obtener más de 1,000 cilindros de biopsias de tejidos incluidos en un solo bloque de parafina. Actualmente, los TMAs se consideran una poderosa herramienta de investigación en laboratorios de Histología y Patología, para la estandarización de técnicas inmunohistoquímica e hibridación in situ entre otras. Sin embargo, uno de los inconvenientes para su uso generalizado es el alto costo de los dispositivos profesionales para tejidos en parafina, y la complejidad en la elaboración de los dispositivos caseros descritos previamente en otros estudios. Este estudio describe paso a paso el proceso de elaboración de cuatro dispositivos caseros útiles para la obtención de matrices de tejido elaborados con materiales que son comunes en hospitales y oficinas. Estos dispositivos son útiles en laboratorios de Histopatología con el fin de obtener bloques de parafina de hasta 360 muestras de tejido, con una inversión de 2 a 15 dólares en la elaboración de cada uno de los dispositivos descritos.

PALABRAS CLAVE: Microarreglo de tejidos; Económico; Método.

\section{REFERENCES}

Battifora, H. Methods in laboratory investigation the multitumor (sausage) tissue block: novel method for immunohistochemical antibody testing. Lab. invest., 55(2):244-8, 1986.

Chen, N. \& Zhou, Q. Constructing Tissue Microarrays Without Prefabricating Recipient Blocks. Am. J. Clin. Pathol., 124(1):103-7, 2005.
Hidalgo, A.; Piña, P.; Guerrero, G.; Lazos, M. \& Salcedo, M. A simple method for the construction of small format tissue arrays. Clin. Pathol., 56(2):144-6, 2003.

Kononen, J.; Bubendorf, L.; Kallioniemi, A.; Bärlund, M.; Schraml, P.; Leighton, S.; Torhorst, J.; Mihatsch, M. J.; Sauter, G. \& Kallioniemi, O. P. Tissue microarrays for high-throughput 
GARCÍA-GARCÍA, R.; RODRÍGUEZ-VIDALES, E. P. \& SOTO-DOMÍNGUEZ, A. Quick and inexpensive method to elaborate tissue punches useful in paraffin tissue microarrays. Int. J. Morphol., 31(1):50-54, 2013

molecular profiling of tumor specimens. Nat. Med., 4(7):8447, 1998.

Martínez, R. P.; Piña, O. A.; Soto, D. A. \& García, R. Histological and Immunohistochemical Comparison of Tissue Samples Processed by the Conventional Technique or the Acetone Simplified Method. Int. J. Morphol., 29(2):575-80, 2011.

Obermann, E. C.; Marienhagen, J.; Stoehr, R.; Wuensch, P. H. \& Hofstaedter, F. Tissue microarray construction from bone marrow biopsies. BioTechniques, 39(6):822-6, 2005.

Packeisen, J.; Buerger, H.; Krech, R. \& Boecker, W. Tissue microarrays: a new approach for quality control in immunohistochemistry. J. Clin. Pathol., 55(8):613-5, 2002.

Packeisen, J.; Korsching, E.; Herbst, H.; Boecker, W. \& Buerger, H. Demystified Tissue microarray technology. Mol. Pathol., 56(4):198-204, 2003.

Pires, A. R.; Andreiuolo, F.da M. \& de Souza, S. R. TMA for all: a new method for the construction of tissue microarrays without recipient paraffin block using custom-built needles. Diagn. Pathol., 1:14, 2006.

Shergill, I. S.; Freeman, A. \& Mundy, A. R. Tissue microarrays in urology. BJU Int., 94(1):22-5, 2004

Van de Rijn, M. \& Gilks, C. B. Applications of microarrays to histopathology. Histopthology, 44(2):97-108, 2004.

Vogel, U. F. \& Bueltmann, B. D. Simple, inexpensive, and precise paraffin tissue microarrays constructed with a conventional microcompound table and a drill grinder. Am. J. Clin.Pathol., 126(3):342-8, 2006

Vogel, U. F. The construction of high-density paraffin tissue microarrays with 0.43 -mm-diameter paraffin tissue core biopsies is technically feasible. Virchows Arch., 453(1):43-46, 2008.

Wang, H.; Wang, H.; Zhang, T. \& Fuller, G. N. Tissue microarrays: applications in neuropathology research, diagnosis, and education. Brain Pathol., 12(1):95-107, 2002.

\author{
Correspondence to: \\ Dr. C. Adolfo Soto-Domínguez \\ Departamento de Histología \\ Facultad de Medicina \\ Universidad Autónoma de Nuevo León \\ Ave. Madero y E. Aguirre-Pequeño, A. P.1563. \\ Monterrey, N.L. 64400 \\ MÉXICO
}

Tel 52-81-8329-4195

Email: ibqasoto@yahoo.com.mx

Received: 04-09-2012

Accepted: 15-11-2012 